\title{
WELFARE AND POVERTY IMPACTS OF AQUACULTURE GROWTH
}

\author{
Shahidur Rashid, Nicholas Minot, and Solomon Lemma
}

\section{Introduction}

Aquaculture is one of the world's fastest growing food-producing sectors, and its share in global fish consumption by humans is projected to grow to more than 60 percent by 2030 (FAO 2014). This growth is remarkable given that the sector was almost nonexistent in the 1950s and its share in total fish production remained below 20 percent until the early 1990s. The underlying implications of this trend are considered to be so significant that they are now commonly termed a "Blue Revolution," and there are good reasons for using the term. Aquaculture holds the promise of meeting most of the world's fish demand without ruining the environment (Economist 2003; Sachs 2007); aquaculture also will be able to help reduce poverty while improving food security and nutritional well-being. ${ }^{1}$ If aquaculture had stopped growing in 1980 - that is, if growth in the world's fish supply depended only on marine and inland capture fisheries-per capita annual fish availability in 2013 would have been only 14.0 kilograms, which is 17 percent lower than the availability in 1980 and about half of the actual availability of 26.8 kilograms in 2013. The consequences of such a scenario are easy to imagine: higher prices, lower consumption, and far greater pressure on marine and inland capture fisheries. The adverse consequences would have been particularly severe for the developing countries of Asia, where fish is an important part of the diet and where fish production and marketing provide the livelihoods for millions of poor households.

Thanks to technological innovation and some deliberate policy actions, the world did not have to live through such a reality. As discussed in the Introduction, calculations from the Food and Agriculture Organization's

1 There is a body of literature on the relationship between aquaculture and food security, poverty, and environment. For further reference, see Ahmed and Lorica (2002) on food security; Toufique and Belton (2014) and Belton, Haque, and Little (2012) on poverty impacts; and Naylor et al. (2000) and Pingali (2001) on environmental impacts. 
(FAO) Aquastat database indicate that Asian countries increased their aquaculture production from 10.8 million metric tons in 1990 to 58.9 million metric tons in 2012, with developing countries accounting for about 86 percent of the total production. Although China has led the way in this growth, some other countries in Asia have also experienced impressive growth in aquaculture since the 1990s. For example, farmed fish production in Bangladesh has increased significantly, with growth in fish availability far exceeding growth in cereal availability during the Green Revolution; there has also been a recent emphasis specifically on aquaculture as opposed to marine or inland capture. ${ }^{2}$ This growth and structural change have contributed to increasing fish availability, reducing the real price of fish, and generating employment, with important implications for poverty reduction and nutritional well-being. ${ }^{3}$

Thus there has been increasing interest in the poverty and income distribution implications of aquaculture growth in Bangladesh. ${ }^{4}$ However, empirical studies have only recently begun to emerge. Even though the literature provides important insights, there remain significant gaps in terms of both conceptual understanding and empirical methodologies. ${ }^{5}$ Conceptually, the aquaculture-poverty linkage literature closely resembles the agriculturalgrowth linkage literature in that almost all available studies hypothesize aquaculture to have both direct and indirect benefits on poverty. However, there are ambiguities regarding the definition and quantification of these direct and indirect benefits. Existing literature has important methodological weaknesses, as almost all available studies are based on nonrepresentative samples. As a result, although these studies provide important insights into selected issues, no generalizable conclusions can be drawn from them. Perhaps the most important gap is that none of the available studies answer the basic question: To what extent has aquaculture growth contributed to poverty reduction?

This chapter attempts to fill these gaps in the literature. In particular, it uses microsimulation methods to analyze the impacts of aquaculture growth

2 According to official data, production of aquaculture fish grew by about 15 percent in the 1990 s, as compared with a growth in rice production of about 3 percent during the Green Revolution.

3 The nutritional implications are particularly important for Bangladesh because fish accounts for 63 percent of animal-sourced protein (FAO 2005) in Bengali diets; it is the most important source of high-quality protein, essential fatty acids, and micronutrients (Roos et al. 2007); and it is the most frequently consumed, nutrient-rich, animal-sourced food among all income groups in Bangladesh (Toufique and Belton 2014).

4 Another reason for increased interests on the aquaculture-poverty link is that donors have taken an active interest in promoting aquaculture.

5 Ahmed and Lorica (2002) presented a conceptual framework, and Toufique and Belton (2014) presented a good summary of available studies of the aquaculture-poverty links in Bangladesh. 
on income distribution and poverty in Bangladesh using an expanded version of Deaton's (1989) model and several rounds of nationally representative household survey data. The chapter is organized as follows: The next section presents key trends in aquaculture production, exports, consumption, and prices in Bangladesh. An overview of the concepts and previous research is followed by a description of the data and methods used in the chapter. The results of the welfare impact of real price decline and productivity growth are then presented. The chapter concludes with a summary and implications.

\section{Trends in Aquaculture in Bangladesh}

\section{Production}

Bangladesh has made remarkable progress in promoting aquaculture. From $1983 / 1984$ to $1992 / 1993$ the average annual production of aquaculture fish from inland fisheries was only about 178,000 metric tons; this number jumped to about 1.3 million metric tons in the most recent decade (Table 5.1). Production of capture and marine fisheries also increased in absolute terms since 1983/1984, but their average shares in total production declined from 53 to 36 percent and from 26 to 19 percent, respectively. In 2015/2016, the latest year for which data are available, total aquaculture production was 2.1 million metric tons, equivalent to 56 percent of the total fish production of 3.7 million metric tons (Shamsuzzaman et al. 2017).

Of the four subcategories of culture fisheries, pond culture has experienced the fastest growth. Average annual pond fish production increased from about 150,000 metric tons in the 1980 s to more than 1.0 million metric tons since 2008 , equivalent to about 80 percent of the total culture production of 1.3 million metric tons. The growth has been faster in recent years, with production from pond culture jumping from 750,000 metric tons in $2007 / 2008$ to 1.45 million metric tons in 2012/2013. Shrimp production, which receives much more attention in policy discussion, increased only by about 65,000 metric tons during the same period. Another new development in aquaculture in Bangladesh is the seasonal production of cultured fish in haors and baors (the depressions that get flooded during the monsoon season). The Department of Fisheries (DoF) began collecting data on seasonal culture fish production in $2009 / 2010$, when it recorded a total production of about 46,000 metric tons; this number increased to 201,000 metric tons by $2012 / 2013$. Thus this appears to be another growth area for Bangladesh aquaculture. 
TABLE 5.1 Trends in fish production in Bangladesh, 1983/1984-2012/2013

\begin{tabular}{lcccccc}
\hline & \multicolumn{5}{c}{ Annual average production (metric tons) and production shares } \\
\cline { 2 - 7 } Sources & $1983 / 1984-$ & & $1993 / 1994-$ & & $2003 / 2004-$ & \\
\hline Inland fisheries & $1992 / 1993$ & Shares (\%) & $2002 / 2003$ & Shares (\%) & $2012 / 2013$ & Shares (\%) \\
Capture & & & & & & \\
$\quad$ River & 175,285 & 20.6 & 151,561 & 10.0 & 140,552 & 5.1 \\
Sunder ban & 6,852 & 0.8 & 9,865 & 0.6 & 18,220 & 0.7 \\
Beel (lake) & 47,397 & 5.6 & 67,403 & 4.4 & 79,136 & 2.9 \\
Kaptai lake & 3,714 & 0.4 & 6,490 & 0.4 & 8,096 & 0.3 \\
Flood lands & 220,170 & 25.8 & 404,291 & 26.5 & 728,193 & 26.4 \\
Total & 453,418 & 53.2 & 639,610 & 42.0 & 974,197 & 35.3 \\
Culture & & & & & & \\
Ponds & 153,258 & 18.0 & 479,867 & 31.5 & $1,010,184$ & 36.6 \\
Semiclose & 1,293 & 0.2 & 3,277 & 0.2 & 5,261 & 0.2 \\
Baors/culture & - & - & - & - & 107,782 & 3.9 \\
Shrimp & 23,378 & 2.7 & 79,611 & 5.2 & 151,610 & 5.5 \\
Total & 177,929 & 20.9 & 562,755 & 37.0 & $1,274,837$ & 46.1 \\
Marine fisheries & & & & & & \\
Industrial & 11,393 & 1.3 & 17,411 & 1.1 & 42,805 & 1.5 \\
Artisanal & 210,092 & 24.6 & 303,123 & 19.9 & 471,245 & 17.1 \\
Total & 221,485 & 26.0 & 320,534 & 21.0 & 514,050 & 18.6 \\
National total & 852,832 & 100.0 & $1,522,899$ & 100.0 & $2,763,084$ & 100.0 \\
\hline
\end{tabular}

Source: Based on data compiled by the authors from Fisheries Statistical Year Book of Bangladesh (1983-2013), published by the DoF's Ministry of Fisheries and Livestock.

Note: $-=$ data not available.

\section{Exports}

Bangladesh exports seven categories of fish products-frozen shrimp, frozen fish, dry fish, salted fish, shark fin, turtle, and others; shrimp is by far the largest export in terms of value and volume. Of the total export of 85,000 metric tons in 2012/2013, more than 50,000 metric tons (or about 60 percent) was shrimp produced by large commercial farmers with the primary objective of exporting. Shrimp is mainly exported to the United States of America (26\%), Belgium (21\%), the United Kingdom (13\%), Germany (8\%), and the Netherlands (5\%) (Kabir 2015, percentages based on data from fiscal year 2010/2011). The share of shrimp in the total export value was even larger, at 81 percent of the total export of $\$ 533$ million. By contrast, the total volume of frozen fish was only about 11,000 metric tons, which included not 
only farm-raised fish but also marine and other capture fisheries. Therefore the actual volume of aquaculture fish export was much smaller than 11,000 metric tons, which is less than 1 percent of the 1.3 million metric tons of cultured fish. These numbers imply that the growth in the production of common aquaculture fish varieties is overwhelmingly driven by domestic demand. This is a key point because multiplier effects are much larger, both in terms of nutrition and income generation, for aquaculture than for other fish subsectors not considered in this study.

\section{Consumption}

The small volume of nonshrimp aquaculture exports indicates that the growth in production has translated into increased consumption at the aggregate level. However, it tells little about the patterns of consumption by location, gender, and income groups, which are central to drawing welfare implications. To this end, this chapter analyzes three rounds of Household Income and Expenditure Survey (HIES) data. The only problem in carrying out this analysis is that HIES does not clearly disaggregate nonshrimp aquaculture from other types of fish consumption, especially from inland capture fisheries. The authors follow Toufique and Belton's (2014) strategy of categorizing fish into four major groups: (1) primarily aquaculture, (2) inland capture and culture, (3) primarily inland capture, and (4) primarily marine. Table 5.2 presents the results of the analysis. The aggregate estimates of rural and urban consumption are fairly similar to those in Toufique and Belton (2014), although two additional dimensions are added to this analysis: disaggregation by gender and by income quintile.

Three main points can be drawn from the results. First, fish consumption has increased for every category of household shown-rural, urban, male, female — as well as for each income quintile. At the national level, per capita annual fish consumption increased from 13.4 kilograms in 2000 to 18.1 kilograms in 2010, implying 35 percent growth over the decade or 3 percent per year. This achievement is remarkable because, not too long ago, achieving 18.0 kilograms per capita annual consumption was a national target and seen as a potential for aquaculture growth. This goal is reflected in an FAO (2005) report: "The present per capita annual fish consumption in Bangladesh stands at about $14 \mathrm{~kg} /$ year against a recommended minimum requirement of $18 \mathrm{~kg} /$ year; hence there is still need to improve fish consumption in the country." Now that the country has achieved the target, perhaps a different set of questions needs to be asked. In particular, policies can now focus on improving distribution across income groups and perhaps accessing international markets. 
TABLE 5.2 Changes in annual per capita fish consumption (kilograms per person per year) in Bangladesh, 2000-2010

\begin{tabular}{|c|c|c|c|c|c|c|c|c|c|c|c|}
\hline \multirow[b]{2}{*}{ Year } & \multirow[b]{2}{*}{ Fish sources } & \multicolumn{2}{|c|}{ Location } & \multicolumn{2}{|c|}{$\begin{array}{l}\text { Sex of the } \\
\text { household } \\
\text { head }^{*}\end{array}$} & \multicolumn{6}{|c|}{ Income quintile } \\
\hline & & Rural & Urban & Male & Female & 1st & 2nd & 3 rd & 4th & Richest & All \\
\hline \multirow[t]{5}{*}{2000} & Primarily aquaculture & 3.4 & 3.9 & 3.3 & 3.5 & 1.6 & 2.3 & 3.0 & 3.9 & 6 & 3.5 \\
\hline & $\begin{array}{l}\text { Inland capture and } \\
\text { culture }\end{array}$ & 4.5 & 3.8 & 5.1 & 4.3 & 3.2 & 4.0 & 4.5 & 4.8 & 5.1 & 4.4 \\
\hline & $\begin{array}{l}\text { Primarily inland } \\
\text { capture }\end{array}$ & 3.6 & 3.5 & 3.6 & 3.6 & 2.8 & 3.6 & 3.5 & 4.0 & 3.9 & 3.6 \\
\hline & Primarily marine & 2.0 & 3.6 & 3.0 & 2.3 & 0.8 & 1.3 & 2.3 & 3.0 & 3.6 & 2.3 \\
\hline & Total & 13.6 & 14.9 & 15.0 & 13.7 & 8.4 & 11.2 & 13.3 & 15.7 & 18.5 & 13.4 \\
\hline \multirow[t]{5}{*}{2005} & Primarily aquaculture & 5.5 & 6.2 & 6.5 & 5.6 & 3.2 & 4.0 & 4.8 & 6.3 & 8.7 & 5.7 \\
\hline & $\begin{array}{l}\text { Inland capture and } \\
\text { culture }\end{array}$ & 5.1 & 4.6 & 5.7 & 4.9 & 4.6 & 4.5 & 4.7 & 5.1 & 5.5 & 4.9 \\
\hline & $\begin{array}{l}\text { Primarily inland } \\
\text { capture }\end{array}$ & 2.7 & 3.4 & 2.8 & 2.9 & 2.3 & 2.4 & 2.7 & 3.1 & 3.4 & 2.9 \\
\hline & Primarily marine & 1.5 & 4.1 & 2.5 & 2.1 & 1.3 & 1.6 & 2.0 & 2.2 & 3.1 & 2.1 \\
\hline & Total & 14.7 & 18.3 & 17.5 & 15.5 & 11.4 & 12.4 & 14.2 & 16.8 & 20.8 & 15.6 \\
\hline \multirow[t]{5}{*}{2010} & Primarily aquaculture & 7.5 & 7.8 & 8.2 & 7.5 & 5.3 & 6.2 & 6.7 & 8.5 & 10.0 & 7.5 \\
\hline & $\begin{array}{l}\text { Inland capture and } \\
\text { culture }\end{array}$ & 5.3 & 6.4 & 6.4 & 5.5 & 4.7 & 4.9 & 5.3 & 5.9 & 6.7 & 5.6 \\
\hline & $\begin{array}{l}\text { Primarily inland } \\
\text { capture }\end{array}$ & 2.4 & 3.2 & 2.9 & 2.6 & 2.0 & 2.2 & 2.5 & 2.8 & 3.3 & 2.6 \\
\hline & Primarily marine & 1.6 & 4.5 & 2.8 & 2.3 & 1.3 & 1.4 & 1.9 & 2.7 & 4.0 & 2.4 \\
\hline & Total & 16.7 & 21.9 & 20.2 & 17.8 & 13.2 & 14.6 & 16.4 & 19.8 & 23.9 & 18.1 \\
\hline \multicolumn{2}{|c|}{ Change since $2000(\%)$} & 23.8 & 46.9 & 34.7 & 29.9 & 57.1 & 30.4 & 23.3 & 26.1 & 29.2 & 35.1 \\
\hline
\end{tabular}

Source: Authors' calculations from BBS HIES rounds 2000, 2005, 2010.

Note: * The differences between mean consumptions are statistically significant.

Second, in relative terms, households in the bottom two income quintiles experienced the fastest growth in fish consumption between 2000 and 2010. The poorest households increased their consumption by more than 57 percent-larger than any other income groups in Table 5.2. This finding is consistent with studies suggesting that both price and income elasticity of demand for fish are higher (in absolute value) for the poor than for richer households (Dey, Alam, and Bose 2010). Finally, the results show that levels of fish consumption are diverging between urban and rural households. In 2000 per capita consumption in urban households was 14.9 kilograms-only about 10 percent higher than consumption by rural households. In 2010 per 
capita annual consumption by urban households jumped to almost 22.0 kilograms-about 31 percent higher than for rural households.

\section{Price Trends}

Since the main way that the boom in Bangladeshi aquaculture helps nonproducers is through the price effect, it is important to explore trends in fish prices over this period. Estimates from the HIES data suggest that fish prices declined between 2000 and 2005 but increased again in 2010. The HIES data refer to unit values of farm-level sales, not prices per se, and may be influenced by seasonality and changes in quality.

More reliable data are collected by the DoF on a regular basis in larger wholesale markets. Figure 5.1 presents trends in market prices of a few popular varieties, along with three point estimates from the HIES data. The DoF market prices are higher than the HIES producer prices because of the transaction costs of collecting and transporting fish to wholesale markets. Except for ilish (primarily a marine fish), all prices have been declining in real terms since 2002, which is consistent with growth of aquaculture. ${ }^{6}$ For instance, commercial production of non-native pangas began in Mymensingh in 1993 (Belton, Haque, and Little 2012), and the DoF began collecting high-frequency price data for pangas and other cultured fish only in the early 2000s. The prices of both pangas and smaller carps (two main varieties of culture fish) have been declining ever since the DoF began recording prices in the early 2000s. Finally, real prices of all fish varieties, both inland and marine, increased rapidly in the 1980s, which was when the Green Revolution took root, rice prices fell, and the economy enjoyed overall growth.

This last point was the subject of much debate in the 1990s. One set of studies argued that income growth was not sufficient to improve nutrition (see, for example, Behrman and Deolalikar 1987; Bouis and Haddad 1992); another strand refuted it (see, for instance, Subramanian and Deaton 1996). A recurrent observation at the time was that although the Green Revolution resulted in declining rice prices, prices of other food items-such as pulses, vegetables, fish, and animal products-were increasing. For instance, Bouis (2000) reported that although rice prices in selected Asian countries declined by 40 percent, the real prices of pulses, vegetables, and animal products had increased 25-50 percent since the onset of the Green Revolution. Figure 5.1

6 Ilish is from the shad family of marine fish. In monsoon season they swim toward upstream rivers, like the Padma. The fish are caught at both the Bay of Bengal and the large rivers. This popular fish in Bengal has a rapidly growing market in the countries of Europe, the Middle East, and North America, where there are Bangladeshi immigrants or migrants. 


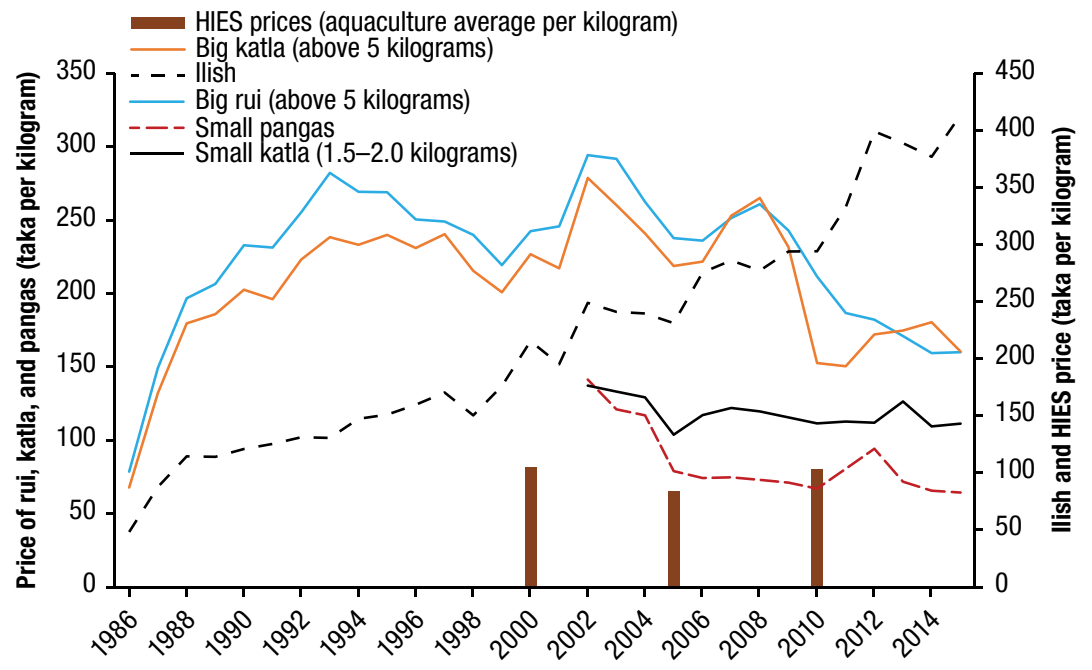

Source: Authors' construction based on the Bangladesh DoF price series $(1994,1997,2006$, and 2015) and BBS HIES data (2010).

demonstrates that this is no longer a concern in Bangladesh, at least in the case of fish; real prices have been declining for all fish varieties, except marine fish, which is largely consumed by the rich and middle-income groups. ${ }^{7}$

The empirical evidence presented suggests that demand has increased with population growth and higher incomes, but supply has increased even more rapidly, resulting in a decline in real price. Because Bangladesh has experienced sustained economic growth, and because aquaculture is a small part of the country's overall economy, it is safe to assume that the shift in demand curve has resulted mainly from overall growth, not aquaculture per se. Given that aquaculture's share in gross domestic product is small, its contribution to the shift in demand should also be relatively small. This suggests that the shift in the supply curve has been the main channel through which aquaculture has contributed to welfare. This is the point of departure of our analysis.

7 An emerging body of literature suggests that the prices of small indigenous species (SIS), which used to be consumed by the poor, are increasing. Studies suggest that because of the way SIS are eaten, their contribution to Recommended Nutritional Intake (RNI) is higher. For a detailed analysis on Bangladesh, see Bogard et al. (2015). 


\section{Concepts and Previous Research}

The conceptual framework for analyzing the welfare implications of aquaculture growth is no different from that for any other economic sector. Following Hirschman's (1957) work in Latin America, many studies have examined linkages between economic sectors. The agricultural growth linkage literature made a distinction between direct and indirect effects in terms of improving rural employment and household well-being (Johnston and Mellor 1961; Mellor and Lele 1972; Adelman and Morris 1973). This literature was a strong force in changing the then-prevailing views-mainly emerging from Latin America-that public investment should be directed toward the industrial sector; this view was based on the presumption that public investment had greater linkages to the overall economy. The underlying ideas of this strand of literature continue to be relevant, as reflected in the recommendations of the World Bank's (2008) World Development Report and de Janvry and Sadoulet's (2010) studies of China.

The central premise of the agricultural growth linkage literature is that the growth in agriculture resulting from the alleviation of supply constraintssuch as technological innovation or infrastructural improvement-generates higher multiplier effects (or growth links) through increased demand of nontradable goods outside of agriculture. ${ }^{8}$ The existing aquaculture poverty linkage literature diverges significantly from this conceptual framework, as is evident in several studies. This chapter builds on two studies that discuss conceptual issues of aquaculture development and their implications for empirical methods and interpretation of results. Ahmed and Lorica (2002) argued that adoption of new aquaculture technology could affect food security through three pathways: income links, employment links, and consumption links. In the income link, the incremental income from aquaculture production improves the ability of households to diversify their diet and consume higher-quality foods. In the employment link, better diets (including more fish) raise the labor productivity of households involved in aquaculture. In the

8 To illustrate the point, suppose that (1) a rural economy is divided into two sectors, agriculture and nonagriculture; (2) marginal propensity to consume (MPC) is low, at 0.5 , for agricultural commodities; and (3) MPC is high, at 0.9, for nonagricultural commodities. The second and third assumptions are particularly realistic for poor economies in that a large share of incremental income is likely to be spent on nonagricultural goods and services (for example, housing, clothing, education, and other nontradables) than on agricultural goods (for example, rice and wheat). Given these assumptions, multiplier effects for nonagriculture, given by $M_{n a}=\frac{1}{(1-0.9)}=10$, will be five times larger than the multiplier effects of agriculture, given by $M_{a}=\frac{1}{(1-0.5)}=2$. This was the key insight of Johnston and Mellor's (1961) seminal study, as well as of many subsequent studies, on the role of agriculture in economic development. 
consumption link, aquaculture technology adoption has both direct effects (through consumption from own production) and indirect effects (through lower fish prices, leading to increased consumption among nonproducers).

Although Ahmed and Lorica (2002) provide a comprehensive discussion of the links between aquaculture and food security, they do not propose a strategy to measure these links. If income rises among aquaculture producers, how much can be attributed to aquaculture per se (income channel) and how much can be attributed to improved labor productivity (employment channel)? Similarly, if fish consumption rises among producers, how much is attributed to income growth (income channel) and how much to the lower (implicit) price of fish (consumption link)?

A recent study by Toufique and Belton (2014) extend the Ahmed-Lorica framework in two ways: (1) they provide more nuance to direct and indirect links, and (2) they adapt a framework for assessing the degree to which aquaculture growth is pro-poor. The study defines the following four links: direct consumption links (increased consumption from own production), indirect consumption links (increased availability and accessibility of fish), direct income links (increased income for aquaculture producers), and indirect income links (employment in the fish value chain and consumption links).

The other contribution of Toufique and Belton (2014) is that they present a conceptual framework for assessing whether aquaculture growth is pro-poor. Drawing from the pro-poor growth literature proposed in Ravallion (2004, 2009) and Kakwani, Khandker, and Son (2004), they classify four types of pro-poorness: benchmarked, weakly pro-poor, strong relative pro-poor, and strong absolute pro-poor. Growth in aquaculture is defined as benchmarked pro-poor if it is associated with an increase in fish consumption by households below the poverty line; weakly pro-poor if fish consumption by the poor increases at a faster rate than in the past; strong relative if fish consumption by the poor increases at a faster rate than by the nonpoor; and strong absolute if the amount of fish consumed by the poor is higher than by the nonpoor.'

Although this characterization helps illustrate the pro-poorness of aquaculture, it has some limitations. The original pro-poor economic growth classification applied to the entire economy, not to any particular sector within an economy. More specifically, pro-poor growth literature compares two measurable outcomes-growth and poverty-that are identifiable. This is not the case for a given sector, as both growth and overall poverty reduction can be influenced by the economy's other sectors. The key variable in Toufique

9 Poor/nonpoor distinction is based on the national poverty line generated by the BBS. 
and Belton's framework - that is, fish consumption-can also be affected by economic factors outside of aquaculture. For example, Toufique and Belton (2014) state that "aquaculture has proven unequivocally pro-poor in terms of the 'indirect consumption' pathway." An implicit assumption of this conclusion is that the increase in fish consumption resulted from the growth in aquaculture alone. However, an increase in fish consumption can be caused by a host of other factors, including growth in other sectors and subsectors. In this chapter's assessment, all of the available evidence confirms that there has been an increase in fish consumption by all income groups and that the real prices have declined due to technological innovation and a rightward shift in the supply curve. But neither of these can be attributed to the growth in aquaculture alone, as there are other contributing factors, including years of overall economic growth.

In this chapter we propose a strategy for estimating the contribution of aquaculture development to overall income growth and poverty reduction. As described in the next section, we extend methods originally proposed by Deaton (1989) to estimate the distributional effect of price and income changes attributable to aquaculture development.

\section{Data and Methods}

\section{Data}

This study uses three rounds of Household Income and Expenditure Survey (HIES), conducted by the Bangladesh Bureau of Statistics (BBS) in collaboration with the World Bank. The sampling methods and the key results from various rounds of the HIES are presented in HIES reports produced after the completion of each round..$^{10}$ Although this chapter uses three rounds of surveys $(2000,2005,2010)$ to explore trends in aquaculture, the microsimulation analysis is based on the latest round (2010). The sampling from that round was based on the Integrated Multipurpose Sample, which consisted of 1,000 primary sampling units. This unit is defined as two or more contiguous enumeration areas used in the 2001 Bangladesh census. Following a two-stage stratified random sampling method, a total of 12,240 households were sampled, of which 7,840 were from rural areas and 4,400 were from urban areas. Sampling weights from the HIES are used in all calculations to compensate for oversampling and undersampling of households in different locations.

10 The report on the 2010 round of the HIES is available from the BBS. 
In addition, secondary data from other sources were used. Production data, disaggregated by location and sources, were compiled from the Department of Fisheries (DoF) Fisheries Yearbook published by the Ministry of Fisheries and Livestock. This yearbook is based on the Fisheries Resources Survey System administered by the DoF. Historical data on fish prices, disaggregated by location and varieties, and on export-import data were also obtained from the DoF. These data were particularly helpful in analyzing the trends and triangulating the estimates generated from the HIES data.

\section{Methodology}

This study employs an expanded version of Deaton's (1989) model for analyzing the welfare implications of food price changes. Deaton's model has been widely used to analyze the welfare effects of price shocks, most notably following the 2007/2008 global food crisis (Minot and Goletti 1998; Ivanic and Martin 2008). Deaton (1989) represents the proportional impact on real income of a commodity price change as:

$$
\frac{d Y}{Y}=\left(\frac{P Q}{Y}-\frac{P C}{Y}\right) \frac{d P}{P}
$$

where $Y$ is household income (or expenditure), $P$ is the price of the commodity, $Q$ is the quantity produced, and $C$ is the quantity consumed. Thus, $P Q / Y$ is the value of production of the commodity as a proportion of income, $P C / Y$ is the value of consumption of the commodity as a proportion of income, and $d P / P$ is the proportional change in the price of the commodity. Deaton calls the expression in parentheses the net benefit ratio (NBR). It can be considered the short-term elasticity of welfare with respect to the commodity price.

We extend this welfare measure in three ways. First, we add a term to reflect changes in income, since we plan to simulate the impact of technology improvements that shift the supply of aquaculture products. Second, we add second-order terms to reflect the welfare-enhancing responses of producers and consumers to price changes. And third, we drop the assumption that producer prices and consumer prices change by the same proportion. The result, shown below, is the expression we used to estimate the proportional impact on the real income of a household resulting from technological change and the resulting price changes:

$$
\frac{d Y}{Y}=\frac{P_{p} Q}{Y} \theta \frac{d Q}{Q}+\frac{P_{p}(Q+d Q)}{Y} \frac{d P_{p}}{P_{p}}+\frac{1}{2} \varepsilon_{s} \frac{P_{p} Q}{Y}\left(\frac{d P_{p}}{P_{p}}\right)^{2}-\frac{P_{c} C}{Y} \frac{d P_{c}}{P_{c}}-\frac{1}{2} \varepsilon_{D} \frac{P_{c} C}{Y}\left(\frac{d P_{c}}{P_{c}}\right)^{2}
$$

where $P_{p}$ is the producer price of aquaculture products, $Q$ is the household production of aquaculture products, $\theta$ is the ratio of producer surplus (profit) to gross revenue in aquaculture, $\varepsilon_{S}$ is the elasticity of supply, $P_{c}$ is the retail 
price of aquaculture products, $C$ is the quantity of aquaculture products consumed by the household, and $\varepsilon_{D}$ is the price elasticity of demand for aquaculture products.

The first three terms describe the effect of technological change and changes in the producer prices on aquaculture producers. More specifically, the first term on the right side describes the producer surplus from the technological shift in aquaculture supply as a share of household income. This is calculated as the product of (a) the share of gross aquaculture income in total income, (b) the ratio of net to gross income in aquaculture, and (c) the proportional shift in supply. The second term describes the first-order proportional effect on producer income of the change in aquaculture producer prices (before any price response). The third term is the second-order proportional effect on producer income of the change in producer prices.

The last two terms describe the effect of changes in aquaculture retail prices on consumers of aquaculture production. The fourth term is the first-order proportional effect on real income of changes in retail prices of aquaculture products (before any price response). The fifth term is the secondorder proportional effect on real income of changes in retail prices of aquaculture products.

Since we are simulating an increase in aquaculture supply resulting in a reduction of aquaculture prices, $d Q / Q>0, d P_{P} / P_{P}<0$, and $d P_{c} / P_{c}<0$. This implies that the first term is positive, reflecting the benefits from technological improvement. The second term is negative, measuring the loss in aquaculture income due to lower prices. The third term is positive, as producer response to the price reduction partially offsets the impact of the decline in prices. The fourth term (including the negative sign) is positive, reflecting the gains to consumers from lower prices for aquaculture products. And the last term is also positive, as the consumer response to lower prices further enhances welfare.

To estimate the welfare impact for each household in the Bangladesh HIES, we need to combine data from the household survey with information on price and production trends, and some assumptions about the market for aquaculture products. $P_{p} Q / Y$ represents the value of aquaculture production as a share of income, also called the production share, while $P_{c} C / Y$ is the value of aquaculture consumption as a share of income, also called the consumption share. These are calculated for each household in the 2000 Bangladesh HIES. The value of household consumption expenditure, $Y$, a proxy for household income, is also calculated from the HIES. The proportional change in producer prices, $d P_{p} / P_{p}$, is based on the weighted average of the inflation-adjusted 
producer price of three fish species widely raised in aquaculture, big rui (more than 5 kilograms), large katla (more than 5 kilograms), and ilish in Kuhlna (the division with the largest aquaculture production). Between 2000 and 2010 the weighted average of the real producer prices fell 36 percent. The proportional change in consumer prices, $d P_{c} / P_{c}$, is calculated as the weighted average of the inflation-adjusted retail prices of the same three species in Dhaka (the main consumption center). This weighted price decreased 45 percent over the same period.

We adopt a price elasticity of demand for aquaculture products from Dey, Alam, and Paraguas (2011), a comprehensive study of fish demand in Bangladesh. They provide compensated and uncompensated elasticity estimates for eight types of fish and seafood products as well as information on consumer spending on each. Based on information provided by Toufique and Belton (2014) on the main source of each type of fish in Bangladesh (marine capture, inland capture, and aquaculture), we used the elasticity estimates of five of the eight types: Indian carp, exotic carp, live fish, tilapia, and high-value fish. We calculated the value-weighted average of the compensated price elasticities of demand for these five types of fish. The compensated (or Hicksian) elasticities are appropriate for calculating welfare impact, although the difference between compensated and uncompensated demand elasticities is modest in this case. The weighted-average Hicksian demand elasticity for aquaculture products is -0.47 .

Estimated supply elasticities for aquaculture are more difficult to find. In the absence of recent estimates for Bangladesh, we adopt estimates by Kumar, Dey, and Paraguas (2006) of the supply elasticities for three aquaculture products in India: tilapia, milkfish, and shrimp/prawns. We use the simple average of these three elasticities: 1.33 . Given the uncertainty about the elasticity estimates, we carried out an analysis of the sensitivity of the results to alternative elasticity estimates. The results are quite similar with no major qualitative differences. These results are available from the authors.

Between 2000 and 2010 the quantity of aquaculture products increased by 104 percent. Taking into account population growth over this period, this represents a per capita increase of 76 percent. We use this figure to represent the supply shift, although this is a conservative estimate because it does not take into account the fact that the increase in output occurred in spite of lower fish prices. To calculate producer surplus, we need an estimate of $\theta$, the ratio of producer surplus to the gross value of production. The simplest assumption is that the supply function has a constant elasticity, implying a double-log functional form. Given our adoption of a supply elasticity of 1.33 , the area under 
the supply curve (costs) is 42.9 percent of the area representing gross revenue. This implies that $\theta$, ratio of net revenue to gross revenue, is approximately 0.571. In other words, the producer surplus can be calculated as 57.1 percent of the gross value of aquaculture production.

We now have the data and parameter assumptions needed to estimate the proportional change in income for each household in the survey, taking into consideration the importance of aquaculture production and consumption in their income. With the welfare effect of the price and technology changes for each household, it is possible to aggregate the results to the national level using the sampling weights. The results are also aggregated to groups of households defined by location (urban or rural), sex of head of household, region, occupation (fish farmer or not), and income quintile. For each group of households we focus on two measures of improvement: the average proportional change in real income $(d Y / Y)$ and the change in the incidence of headcount poverty.

\section{Welfare Implications of Aquaculture Growth}

\section{Market Positions and Net Benefit Ratios}

Based on data from the 2000 HIES survey, Table 5.3 shows descriptive statistics for the NBR of aquaculture for various types of households in Bangladesh. The first column indicates the proportion of all households in that category. The next three columns show the average production ratio $\left(P_{p} Q / Y\right)$, the average consumption ratio $\left(P_{c} C / Y\right)$, and the average $\mathrm{NBR}\left(P_{p} Q / Y-P_{c} C / Y\right)$, respectively. The last three columns present the share of households in that category that are net sellers, autarkic (neither buying nor selling), or net buyers. The results are disaggregated by household location (rural or urban), administrative division, the sex of the household head, fishing practices, and income quintile.

Starting with the national estimates (the last row of the table), aquaculture production accounts for 2.07 percent of income, while aquaculture consumption represents 3.77 percent of income, giving an NBR of -1.7 percent. ${ }^{11}$ This means that a 10 percent increase in all aquaculture prices would result in a 0.17 percent decrease in income for Bangladeshi households. The last three columns of the last row indicate that about 80.0 percent of households are net buyers, 12.7 percent are autarkic, and about 7.5 percent are net sellers.

11 Throughout this analysis total household consumption expenditure is used as a proxy for income because income is subject to more measurement errors. 
TABLE 5.3 Net positions of households in aquaculture fish in Bangladesh

\begin{tabular}{|c|c|c|c|c|c|c|c|}
\hline \multirow[b]{2}{*}{$\begin{array}{l}\text { Household } \\
\text { category }\end{array}$} & \multirow{2}{*}{$\begin{array}{c}\text { Percentage } \\
\text { of all } \\
\text { households }\end{array}$} & \multicolumn{3}{|c|}{$\begin{array}{l}\text { Percentage of total } \\
\text { income }\end{array}$} & \multicolumn{3}{|c|}{$\begin{array}{c}\text { Percentage of households in } \\
\text { each category }\end{array}$} \\
\hline & & $\begin{array}{l}\text { Production } \\
\text { ratio }\end{array}$ & $\begin{array}{l}\text { Consumption } \\
\text { ratio }\end{array}$ & $\begin{array}{l}\text { Net benefit } \\
\text { ratio }\end{array}$ & $\begin{array}{l}\text { Net } \\
\text { seller }\end{array}$ & Autarkic & $\begin{array}{c}\text { Net } \\
\text { buyer }\end{array}$ \\
\hline \multicolumn{8}{|l|}{ Location } \\
\hline Rural & 80 & 2.51 & 3.90 & -1.38 & 9.1 & 13.2 & 77.6 \\
\hline Urban & 20 & 0.32 & 3.27 & -2.96 & 1.2 & 10.4 & 88.4 \\
\hline \multicolumn{8}{|c|}{ Sex of household head } \\
\hline Male & 91 & 2.21 & 3.80 & -1.59 & 8.0 & 11.9 & 80.1 \\
\hline Female & 9 & 0.61 & 3.48 & -2.86 & 2.5 & 20.1 & 77.5 \\
\hline \multicolumn{8}{|l|}{ Regional } \\
\hline Barisal & 7 & 1.99 & 2.09 & -0.10 & 9.7 & 34.5 & 55.8 \\
\hline Chittagong & 23 & 1.77 & 4.37 & -2.60 & 5.4 & 12.8 & 81.8 \\
\hline Dhaka & 33 & 1.78 & 3.87 & -2.09 & 6.9 & 8.6 & 84.6 \\
\hline Khulna & 12 & 5.38 & 3.74 & 1.64 & 14.0 & 11.6 & 74.5 \\
\hline Rajshahi & 25 & 1.18 & 3.54 & -2.36 & 6.7 & 12.5 & 80.8 \\
\hline \multicolumn{8}{|l|}{ Occupation } \\
\hline Fish farmer & 23 & 9.06 & 4.94 & 4.12 & 32.9 & 9.2 & 57.9 \\
\hline Other & 77 & - & 3.42 & -3.42 & - & 13.7 & 86.3 \\
\hline \multicolumn{8}{|c|}{ Income quintile } \\
\hline Poorest & 20 & 1.52 & 3.15 & -1.63 & 4.7 & 21.4 & 73.9 \\
\hline 2nd & 20 & 2.21 & 3.67 & -1.45 & 8.1 & 15.1 & 76.8 \\
\hline $3 \mathrm{rd}$ & 20 & 2.35 & 4.16 & -1.81 & 8.6 & 11.8 & 79.7 \\
\hline 4th & 20 & 2.61 & 4.10 & -1.49 & 9.5 & 10.4 & 80.1 \\
\hline Richest & 20 & 1.65 & 3.78 & -2.13 & 6.7 & 4.6 & 88.6 \\
\hline National & 100 & 2.07 & 3.77 & -1.70 & 7.5 & 12.7 & 79.8 \\
\hline
\end{tabular}

Source: Authors' calculations based on the BBS HIES 2000.

Note: $-=$ data not available.

A couple of other results are worth highlighting. First, estimated NBRs are positive only for fish farmers and for households in the Khulna division, implying that these two groups will gain from an increase in aquaculture prices and lose from a decline in prices, at least in the short run. For fish farmers a positive NBR is obvious. For Khulna, the largest fish-producing region in the country, a positive NBR means that the gains to producers from a price increase will outweigh the losses to consumers. Second, among the household categories with negative NBRs, the estimates vary, from as low as -3.42 for 
nonfarmers to as high as -0.10 percent in Barisal. Similarly, the NBR magnitudes vary by income quintile as well. This implies that the impacts of an increase (decrease) in aquaculture fish prices will be felt differently depending on the household categories. For instance, urban households would benefit more, on average, from a price decline than would rural households. However, the magnitude of welfare gain (loss) due to a decrease (increase) in fish prices is small. A doubling of fish prices would lead to only about a 3 percent decline in the welfare of urban households. The same argument goes for male-headed households.

\section{Impacts of Aquaculture Growth on Income Distribution}

This section discusses the distributional impact of improved aquaculture technology leading to an expansion of supply and the lower prices resulting from the shift. As discussed earlier, we estimate the welfare impact of these changes for each household in the HIES survey, then aggregate to different categories of households. Table 5.4 shows the percentage change in real income. Similar to Table 5.3, the results are disaggregated by location, gender of the household head, region, occupation (fish farmer or not), and income quintile. Both shortand long-run impacts of aquaculture growth have been analyzed.

The first column of figures in Table 5.4 shows the baseline level of per capita consumption expenditure. Not surprisingly, urban households are better off than rural ones. Fish farmers are neither poorer nor richer than other households, on average. The second column gives the short-term price effect, excluding the effect of technological improvement and household response to price changes. Starting at the national level, the short-run price effect results in an increase in real income by 0.88 percent. However, non-fish farmers, representing 77 percent of the Bangladeshi population, gain 1.54 percent from the decline in aquaculture fish prices. Fish farmers lose because a decline in prices reduces their revenues. Although small in magnitudes, Khulna as a whole loses as well. This suggests that the reduction in revenue due to a fall in prices outweighs the gain by consumers in the division. This finding is consistent with the fact that Khulna is the largest producer of aquaculture fish in Bangladesh.

The third column of Table 5.4 shows the long-run price effect in terms of the percentage increase in real income. On average, households gain 1.25 percent in real income due to the decline in aquaculture prices. The gains are larger for every group (or the losses are smaller) as households adapt to the price changes. The fourth column presents the percentage of income changes for aquaculture producers. The average gain is 3.33 percent. Every group gains, 
TABLE 5.4 Impacts of aquaculture growth on household income

\begin{tabular}{|c|c|c|c|c|c|}
\hline \multirow[b]{2}{*}{$\begin{array}{l}\text { Household } \\
\text { category }\end{array}$} & \multirow[b]{2}{*}{$\begin{array}{c}\text { Baseline } \\
\text { expenditure } \\
\text { (BDT/capita/ } \\
\text { year) }\end{array}$} & \multirow{2}{*}{$\begin{array}{c}\text { Short-run } \\
\text { price effect } \\
\text { (Percentage- } \\
\text { point change in } \\
\text { poverty) }\end{array}$} & \multicolumn{3}{|c|}{ Long-run effect (Percentage-point change in poverty) } \\
\hline & & & $\begin{array}{c}\text { Only price } \\
\text { effect }\end{array}$ & $\begin{array}{l}\text { Price and } \\
\text { quantity effect } \\
\text { on fishers }\end{array}$ & $\begin{array}{l}\text { Price and quantity } \\
\text { effect on all } \\
\text { households }\end{array}$ \\
\hline & & $(\ldots \ldots \ldots \ldots)$ & $\ldots \ldots . . . \% \mathrm{ch}$ & ge in income. & $(\ldots \ldots \ldots \ldots \ldots \ldots \ldots \ldots)$ \\
\hline \multicolumn{6}{|l|}{ Location } \\
\hline Rural & 11,394 & 0.77 & 1.19 & 3.34 & 2.23 \\
\hline Urban & 17,003 & 1.32 & 1.50 & 3.08 & 1.63 \\
\hline \multicolumn{6}{|c|}{ Sex of household head } \\
\hline Male & 12,475 & 0.84 & 1.23 & 3.34 & 2.12 \\
\hline Female & 13,186 & 1.40 & 1.63 & 2.88 & 1.88 \\
\hline \multicolumn{6}{|l|}{ Regional } \\
\hline Barisal & 11,380 & 0.05 & 0.37 & 2.23 & 1.31 \\
\hline Chittagong & 12,685 & 1.23 & 1.61 & 3.97 & 2.38 \\
\hline Dhaka & 13,886 & 1.02 & 1.37 & 3.59 & 2.10 \\
\hline Khulna & 12,563 & -0.28 & 0.38 & 4.03 & 2.45 \\
\hline Rajshahi & 10,822 & 1.11 & 1.39 & 2.53 & 1.87 \\
\hline \multicolumn{6}{|l|}{ Occupation } \\
\hline Fish farmer & 12,418 & -1.13 & -0.10 & 3.33 & 3.33 \\
\hline Other & 12,553 & 1.54 & 1.70 & - & 1.70 \\
\hline \multicolumn{6}{|c|}{ Income quintile } \\
\hline Poorest & 5,774 & 0.84 & 1.12 & 3.04 & 1.70 \\
\hline 2nd & 8,002 & 0.96 & 1.31 & 3.23 & 2.05 \\
\hline $3 r d$ & 10,107 & 0.98 & 1.38 & 3.46 & 2.27 \\
\hline 4th & 13,382 & 0.76 & 1.22 & 3.51 & 2.36 \\
\hline Richest & 25,339 & 0.85 & 1.24 & 3.30 & 2.15 \\
\hline National & 12,519 & 0.88 & 1.25 & 3.33 & 2.11 \\
\hline
\end{tabular}

Source: Authors' analysis based on the BBS HIES 2000.

Note: The data are based on the following assumptions: (1) Consumer and producer prices decline by 45 and 36 percent, respectively. (2) Growth in production is 104 percent. (3) Demand and supply elasticity estimates are -0.47 and 1.33 , respectively. $-=$ data not available. BDT $=$ Bangladeshi taka.

as the gains from technology improvement exceed the losses associated with lower prices. The largest gain is for fish farmers in Khulna, where aquaculture production is concentrated.

The last column shows the percentage of change in real income for all households taking into account both price and technology changes. On average, real household income rises by 2.11 percentage points. Every group benefits, but the size of the gain varies. Rural households (including many fish 
farmers) gain more than urban ones. Male-headed households (who are more likely to be net sellers) gain more than female-headed households. Households in Khulna (many of whom are net sellers) gain more than those in other regions. The poorest gain somewhat less than other income groups. This is because they are less likely to be net sellers of aquaculture products and less likely to benefit from falling prices because fish expenditure is a relatively small portion of their budgets.

\section{Impacts of Aquaculture Growth on Poverty}

Between 2000 and 2010, production of aquaculture fish (excluding shrimp) has more than doubled, and the real prices of major varieties of aquaculture at the retail and farm-gate level declined by 45 percent and 36 percent, respectively. This section presents an analysis of how these changes translate into poverty reduction. We begin by estimating the baseline poverty rate by household categories using the 2000 HIES. The national poverty rate in 2000 was 48.8 percent; rural and urban poverty rates were 52.0 and 35.0 percent, respectively. Therefore these estimates are close to the ones presented in World Bank (2013) and the government's figures based on the HIES data (BBS 2010).

The first column of Table 5.5 shows the poverty rate for each category of household. The poverty rate is similar for male- and female-headed households. Across regions it ranges from 45 percent to 57 percent. It is worth noting that fish farmers have a lower poverty rate ( 44 percent) than other households. The second column assesses how the poverty rates decline in the short run following a reduction in the real price of aquaculture products. Two points should be highlighted from these results. First, the magnitude of overall reduction in poverty due to price change is small: a 45 percent decline in the retail price leads to a 1.07 percentage point decline in poverty. This finding is not surprising in that, on average, aquaculture products account for less than 4 percent of the household budget. Second, a decline in price does not reduce poverty rates among the bottom two quintiles of households. This does not mean that those households do not gain from price decline; rather, it means that the gains are not large enough to pull those households out of poverty. Finally, poverty among fish-farming households increases by 0.56 percentage points due to short-run price effects, which implies that fish-farming households just above the poverty line could slip into poverty when only price decline is considered. However, this simulation does not account for productivity gains and the second-round effects specified in the second equation on page 88 .

The long-run estimates are presented in the last three columns of Table 5.5. The first of these three columns reports the long-run effects of a 
TABLE 5.5 Impacts of aquaculture growth on poverty reduction

\begin{tabular}{|c|c|c|c|c|c|}
\hline \multirow[b]{2}{*}{$\begin{array}{l}\text { Household } \\
\text { category }\end{array}$} & \multirow[b]{2}{*}{$\begin{array}{c}\text { Baseline } \\
\text { poverty rate (\%) }\end{array}$} & \multirow[b]{2}{*}{$\begin{array}{l}\text { Short-run } \\
\text { price effect }\end{array}$} & \multicolumn{3}{|c|}{ Long-run effect } \\
\hline & & & $\begin{array}{l}\text { Price } \\
\text { effects }\end{array}$ & $\begin{array}{c}\text { Price and } \\
\text { quantity effect } \\
\text { on fishers }\end{array}$ & $\begin{array}{l}\text { Price and quantity } \\
\text { effect on all } \\
\text { households }\end{array}$ \\
\hline & & $\ldots \ldots \ldots \ldots \ldots$ & rcentage & tt change in pove & $y \quad \ldots \ldots \ldots \ldots \ldots \ldots .)$. \\
\hline \multicolumn{6}{|l|}{ Location } \\
\hline Rural & 52 & -0.84 & -1.14 & -2.63 & -1.91 \\
\hline Urban & 35 & -0.50 & -0.78 & -2.35 & -0.85 \\
\hline \multicolumn{6}{|c|}{ Sex of household head } \\
\hline Male & 49 & -0.71 & -1.03 & -2.72 & -1.70 \\
\hline Female & 47 & -1.71 & -1.71 & 0.00 & -1.71 \\
\hline \multicolumn{6}{|l|}{ Regional } \\
\hline Barisal & 53 & -0.98 & -1.15 & -3.54 & -2.15 \\
\hline Chittagong & 45 & -0.74 & -1.14 & -3.63 & -1.79 \\
\hline Dhaka & 46 & -0.70 & -1.03 & -2.84 & -1.56 \\
\hline Khulna & 45 & -0.47 & -0.47 & -1.05 & -1.87 \\
\hline Rajshahi & 57 & -1.00 & -1.31 & -2.18 & -1.56 \\
\hline \multicolumn{6}{|l|}{ Occupation } \\
\hline Fish farmers & 44 & 0.56 & -0.10 & -2.63 & -2.63 \\
\hline Others & 50 & -1.21 & -1.39 & - & -1.39 \\
\hline \multicolumn{6}{|l|}{ Income quintile } \\
\hline Poorest & 100 & 0.00 & 0.00 & 0.00 & 0.00 \\
\hline 2nd & 100 & 0.00 & 0.00 & 0.00 & 0.00 \\
\hline $3 r d$ & 44 & -4.33 & -5.82 & -12.2 & -8.49 \\
\hline 4th & 0 & 0.27 & 0.27 & 0.00 & 0.00 \\
\hline Richest & 0 & 0.21 & 0.21 & 0.00 & 0.00 \\
\hline National & 49 & -0.77 & -1.07 & -2.63 & -1.70 \\
\hline
\end{tabular}

Source: Authors' analysis based on BBS HIES 2000.

Note: This set of simulations is based on the following assumptions: (1) Consumer and producer prices decline by 45 and 36 percent, respectively. (2) Growth in production is 104 percent. (3) Demand and supply elasticity estimates are -0.47 and 1.33 , respectively. $-=$ data not available.

decline in prices, taking into account household response; the second column shows the joint impact of price decline and productivity growth on fish-farming households only; and the final column presents the long-run impacts on all households. Four general conclusions can be drawn from these results. First, the long-run poverty impacts are much larger than the short-run impacts. The impact of price decline on poverty in the long run is 1.07 percentage points, which is almost 40 percent larger than the short-run 
impacts. Second, households in the third income quintile benefit the most. The magnitudes of poverty reduction are as high as 12.2 percentage points if only fish-farming households are considered; they are 8.49 percentage points if all households are considered. Since the poverty rate is 49 percent across the population, many households in the third quintile are close to the poverty line. Third, among the other household categories, overall poverty reduction is greatest among fish-farming households (2.63 percentage points), followed by households in Barisal (2.15 percentage points). However, the impacts are also substantial for other divisions. The final points to highlight are that there is no change in the poverty rate for the poorest two quintiles and the richest two quintiles. These households are too far from the poverty line for these changes in income to affect their poverty status.

To summarize, the all-inclusive long-run results suggest that, at the aggregate level, the growth of aquaculture in Bangladesh between 2000 and 2010 was responsible for a 2.11 percent increase in real incomes and a 1.70 percentage point reduction in poverty. Official statistics show that overall poverty in the country declined from 48.9 percent to 31.5 percent during the same period, for a decrease of 17.4 percentage points. As a first approximation, this implies that about 10 percent $(2.06 / 17.4)$ of the overall reduction in poverty can be attributed to the growth in aquaculture during 2000-2010. ${ }^{12}$

\section{Conclusion}

Defying many earlier predictions, global fish production has grown faster than the world's population in the past couple of decades. Aquaculture has been the biggest contributor to this growth, with its share in total fish production rising from about 16 percent in 1990 to more than 50 percent in 2012. This remarkable transformation has important implications for food security, poverty, and environment, especially for developing countries of Asia. This chapter contributes to that literature by clarifying some conceptual issues and presenting the quantitative evidence on the income and poverty impacts of aquaculture growth in Bangladesh.

Conceptually, the aquaculture-poverty linkage literature closely resembles agricultural growth linkage literature. Evolved in the 1960s, the agricultural growth linkage literature demonstrated that in addition to its direct

12 A more in-depth analysis would decompose the sources of poverty reduction by growth in different sectors, taking into account interactions and general equilibrium effects. However, there is no reason to believe that our analysis systematically overestimates the share of poverty reduction that can be attributed to growth in aquaculture. 
benefits, agriculture generates multiplier effects through increased demand of nontradable goods outside of agriculture. The existing studies on aquaculture's link to poverty and income distribution appear to miss this impact channel, however, as they focus only on aquaculture and ignore links to other sectors. The existing empirical literature has two important gaps-problems of generalizability of results and the quantification of income and poverty impacts. Because most of the studies are not based on representative samples, their conclusions cannot be generalized, even though they offer useful insights into the process. Perhaps the most important gap in the literature is that previous studies did not quantify the degree to which aquaculture has contributed to income growth and poverty reduction. This chapter addresses both of these gaps by estimating the income and poverty impacts using nationally representative household survey data from Bangladesh, a country that has been successful in promoting aquaculture and reducing poverty since the early 2000s.

The results of this study suggest that the impacts of aquaculture growth on income distribution and poverty reduction in Bangladesh have been substantial, even though the impacts on households in the bottom income quintile have been modest. We estimate that aquaculture's contribution to income growth between 2000 and 2010 was 2.11 percent, including both price and quantity effects. This income growth has translated into an estimated poverty reduction of 1.7 percentage points nationwide. Although these estimates seem small, they represent a substantial share of overall poverty reduction between 2000 and 2010. For instance, national headcount poverty rates declined from 48.9 percent in 2000 to 31.5 percent in 2010 (World Bank 2013). This implies that the growth in aquaculture has been responsible for almost 10 percent of the overall poverty reduction in Bangladesh during the first decade of the 21st century. Put differently, of the 18 million Bangladeshis who escaped poverty during 2000-2010, more than 2 million of them managed to do so because of aquaculture.

Although these are impressive numbers, this is only part of the story. More analysis is needed to better understand the true benefits and costs of promoting a Blue Revolution strategy. First, a general equilibrium analysis could incorporate additional impact channels, such as through wage rates, which would likely generate larger benefits for the daily wage worker who belongs to the bottom income quintile. Second, it would be useful to explore the nutritional impact of the expansion of aquaculture in Bangladesh through both changes in income and the reduced price of fish and other aquaculture products. Finally, the environmental impact of the Blue Revolution needs to be 
incorporated into the analysis, raising difficult questions regarding the quantification of costs.

\section{References}

Adelman, I., and C. Morris. 1973. Economic Growth and Social Equity in Developing Countries. Stanford, CA, US: Stanford University Press.

Ahmed, M., and M. H. Lorica. 2002. "Improving Developing Country Food Security through Aquaculture Development-Lessons from Asia." Food Policy 27 (2): 125-141.

Bangladesh, DoF (Department of Fisheries). 1994. Fisheries Statistical Year Book of Bangladesh 19921993. Dhaka: Fisheries Resource Survey System, DoF, Ministry of Fisheries and Livestock.

_ 1997. Fisheries Statistical Year Book of Bangladesh 1995-1996. Dhaka: Fisheries Resource Survey System, DoF, Ministry of Fisheries and Livestock.

- 2006. Fisheries Statistical Year Book of Bangladesh 2004-2005. Dhaka: Fisheries Resource Survey System, DoF, Ministry of Fisheries and Livestock.

- 2015. Fisheries Statistical Year Book of Bangladesh 2013-2014. Dhaka: Fisheries Resource Survey System, DoF, Ministry of Fisheries and Livestock.

BBS (Bangladesh Bureau of Statistics). 2000. Household Income and Expenditure Survey 2000. Dhaka.

- 2005. Household Income and Expenditure Survey 2005. Dhaka.

-2010. Report of the Household Income and Expenditure Survey 2010. Dhaka: Ministry of Planning.

Behrman, J. R., and A. B. Deolalikar. 1987. "Will Developing Country Nutrition Improve with Income? A Case Study for Rural South India." Journal of Political Economy 95 (3): 492-507.

Belton, B., M. M. Haque, and D. C. Little. 2012. “Does Size Matter? Reassessing the Relationship between Aquaculture and Poverty in Bangladesh." Journal of Development Studies 48 (7): 904-922.

Bogard, J. R., S. H. Thilsted, G. C. Marks, M. A. Wahab, M.A.R. Hossain, J. Jakobsen, and J. Stangoulis. 2015. "Nutrient Composition of Important Fish Species in Bangladesh and Potential Contribution to Recommended Nutrient Intakes." Journal of Food Composition and Analysis 42: 120-133.

Bouis, H. E. 2000. "Commercial Vegetable and Polyculture Fish Production in Bangladesh: Their Impacts on Household Income and Dietary Quality." Food and Nutrition Bulletin 21 (4): 482-487.

Bouis, H. E., and L. J. Haddad. 1992. "Are Estimates of Calorie-Income Elasticities Too High? A Recalibration of the Plausible Range." Journal of Development Economics 39: 333-364. 
Deaton, A. 1989. "Rice Prices and Income Distribution in Thailand: A Non-parametric Analysis." Economic Journal 99 (395): 1-37.

De Janvry, A., and E. Sadoulet. 2010. "Agricultural Growth and Poverty Reduction: Additional Evidence." World Bank Research Observer 25 (1): 1-20.

Dey, M. M., M. F. Alam, and M. L. Bose. 2010. "Demand for Aquaculture Development: Perspectives from Bangladesh for Improved Planning." Reviews in Aquaculture 2 (1): 16-32.

Dey, M. M., M. F. Alam, and F. J. Paraguas. 2011. "A Multistage Budgeting Approach to the Analysis of Demand for Fish: An Application to Inland Areas of Bangladesh." Marine Resource Economics 26 (1): 35-58.

Economist. 2003. "Fish Farming: The Promise of a Blue Revolution." Accessed December 1, 2017. www.economist.com/node/1974103.

FAO (Food and Agriculture Organization of the United Nations). 2005. "Bangladesh National Aquaculture Sector Overview.” Accessed December 11, 2017. www.fao.org/fishery/ countrysector/naso_bangladesh/en.

- 2014. The State of World Fisheries and Aquaculture: Opportunities and Challenges. Rome: FAO Fisheries and Aquaculture Department.

Hirschman, A. O. 1957. "Investment Policies and 'Dualism' in Underdeveloped Countries." American Economic Review 47 (5): 550-570.

Ivanic, M., and W. Martin. 2008. "Implications of Higher Global Food Prices for Poverty in Low-Income Countries.” Agricultural Economics 39 (s1): 405-416.

Johnston, B. F., and J. W. Mellor. 1961. “The Role of Agriculture in Economic Development.” American Economic Review 51 (4): 566-593.

Kabir, S. H. 2015. Sea Food Export from Bangladesh and Current Status of Traceability. Accessed August 21, 2018. www.unescap.org/sites/default/files/6-\%20\%20Sea\%20Food\%20 Export\%20from\%20Bangladesh-Kabir.pdf.

Kakwani, N., S. Khandker, and H. H. Son. 2004. Pro-Poor Growth: Concepts and Measurement with Country Case Studies. International Poverty Centre Working Paper 1. Brasilia, Brazil: United Nations Development Programme, International Poverty Centre.

Kumar, P., M. M. Dey, and F. J. Paraguas. 2006. "Fish Supply Projections by Production Environments and Species Types in India." Agricultural Economics Research Review 19 (2): $327-351$.

Mellor, J. W., and U. Lele. 1972. “Growth Linkages of New Agricultural Technology.” Indian Journal of Agricultural Economics 18: 10-15.

Minot, N., and F. Goletti. 1998. "Export Liberalization and Household Welfare: The Case of Rice in Vietnam." American Journal of Agricultural Economics 80 (4): 738-749. 
Naylor, R. L., R. J. Goldburg, J. H. Primavera, N. Kautsky, M. C. Beveridge, J. Clay, C. Folke, J. Lubchenco, H. Mooney, and M. Troell. 2000. "Effect of Aquaculture on World Fish Supplies." Nature 405 (6790): 1017-1024.

Pingali, P. 2001. "Environmental Consequences of Agricultural Commercialization in Asia." Environment and Development Economics 6 (4): 483-502.

Ravallion, M. 2004. Pro-Poor Growth: A Primer. Washington, DC: Development Research Group, World Bank.

- 2009. "Defining Pro-Poor Growth: A Response to Kakwani." IPC-IG Collection of One Pagers. Brasilia, Brazil: United Nations Development Programme International Poverty Centre.

Roos, N., M. A. Wahab, C. Chamnan, and S. H. Thilsted. 2007. "The Role of Fish in Food-Based Strategies to Combat Vitamin A and Mineral Deficiencies in Developing Countries." Journal of Nutrition 137 (4): 1106-1109.

Sachs, J. D. 2007. "The Promise of the Blue Revolution: Aquaculture Can Maintain Living Standards while Averting the Ruin of the Oceans." Scientific American 297 (1): 37-38.

Shamsuzzaman, M. M., M. M. Islam, N. J. Tania, M. A. Al-Mamun, P. P. Barnum, and X. Xu. 2017. "Fisheries Resources of Bangladesh: Present Status and Future Direction." Aquaculture and Fisheries 2: 145-156.

Subramanian, S., and A. Deaton. 1996. "The Demand for Food and Calories." Journal of Political Economy 104 (1): 133-162.

Toufique, K. A., and B. Belton. 2014. "Is Aquaculture Pro-Poor? Empirical Evidence of Impacts on Fish Consumption." World Development 64: 600-620.

World Bank. 2008. The World Development Report 2008: Agriculture for Development. Washington, DC.

-2013. Bangladesh Poverty Assessment: Assessing a Decade of Progress in Reducing Poverty 2000-2010. Accessed December 1, 2017. https://openknowledge.worldbank.org/bitstream/ handle/10986/16622/785590NW P0Bang00Box0377348B0PUBLIC0.pdf? sequence $=1$. 
